\title{
ZROZENÍ KVASZOVA ABSOLUTNÍHO IDEALISMU Z DUCHA GEOMETRIE
}

V roce 1998 publikoval Ladislav Kvasz knihu $O$ revolúciách vo vede a ruptúrach v jazyku vedy, v roce 2008 vyšel jeho spis Patterns of Change. Linguistic Innovations in the Development of Classical Mathematics, nyní vychází jeho Prostor mezi geometrií a malírstvím. ${ }^{1}$ Ačkoli Kvasz vydal mezitím ještě několik dalších knih, ty zmíněné na sebe zcela netriviálním způsobem navazují - nikoli lineárně, postupným přidáváním a rozšiřováním témat, ale iterací základního materiálu. Ten je sice v detailech podstatně a extenzivně obměňován, ale celek zůstává stejný, resp. subjektivně řečeno: nyní vidím, že zůstává stejný, protože ho teprve ted’ mám před očima.

V knize $O$ revolúciách byla vedle matematiky v centru Kvaszova zájmu ještě fyzika, v Patterns of Change přibyly významně aspekty didaktické (podle Kvaszovy hypotézy má matematická ontogeneze, tedy výuka dítěte, kopírovat dějinnou fylogenezi), nyní vystupují do popředí otázky malirrsství. Jednotlivě šlo tedy číst příslušné knihy jako určité př́ípadové studie, byt' s nápaditými, někdy i svéráznými výlety do jiných disciplín, od filosofie po dětskou psychologii, se zásobnicí neobyčejně podnětných analogií a nápadů. Že uvedené publikace mají ambici větší, bylo rovněž jasné, ale čtenář se k ní musel dopracovat sám. Vezměme třeba tuto pasáž z Patterns of Change:

„Na začátku matematici přijali jen jedinečnou kladnou hodnotu neznámé, která splnila určité podmínky stanovené ve formulaci matematického problému coby řešení nějaké rovnice. Neznámá takto byla chápána jako ,obrázek ‘ kvantity z reálného světa, přesně tak, jak je tomu v perspektivní reprezentaci. Později, když matematici zavedli substituce (tj. reprezentace reprezentací), objevil se názor, že je třeba jako řešení přijmout všechny kořeny rovnice. To znamenalo, že byla přijata nejen ,pravdivá ${ }^{6}$, tj. kladná řešení, ta s přímým vztahem ke skutečnosti, ale také (užijeme-li Descartův termín), falešná a dokonce ,imaginární . ̌̌ešení takto přestala být ,obrázky“ mimojazykové

$1 \quad$ L. Kvasz, Prostor mezi geometrií a malírstvím. Vývoj pojetí prostoru v geometrii a jeho zobrazování v malírství od renesance po 20. století, Praha 2020. 
skutečnosti a stala se prvkem struktury. Substituce se v mnoha ohledech podobají projekcím projektivní geometrie.“2

Pamatuji si zřetelně, jak silně na mě kdysi toto místo zapůsobilo, nebot' se v něm ukázala možnost aritmetického jazyka poukázat k sobě velmi jednoduchým a přesvědčivým způsobem (dosazením komplexního výrazu do výrazu odkazujícího k nějakému řešení), a navíc se tato sebereflexe, $v$ oblastech exaktních a přírodních věd spíše ignorovaná, projevila hned jako systematická. Co mě ale zaujalo nejvíc, bylo právě spojení tohoto vhledu s geometrickou analogií a filosofickým zobecněním.

Tím se Kvaszova kniha stala více než jenom důvtipným a kuriózním komentářem $\mathrm{k}$ dějinám matematiky, s př́ípadnými výlety do jiných oblastí ducha: začala směřovat $\mathrm{k}$ určitému filosofickému systému, a to nikoli abstraktně, ale různými variacemi zcela konkrétního materiálu, které se nakonec, slovy Dietmara Datha, ,opakováním určitého početního postupu a stálým vkládáním posledních výsledků znovu do programu více a více blíží hledanému řešení“. ${ }^{3}$ Dath tímto popisem odlišuje Hegelovo „iterativní“ budování systému od budování „kumulativně-monografického". Pro mě jsou toto rozdělení a následná charakterizace Kvaszova způsobu práce důležité svým poukazem na sklon k vysvětlování zkušenosti - at' už matematické, fyzikální či umělecké - z ní samé, tedy imanentně, $\mathrm{k}$ čemuž se matematika jako didaktické východisko širších zkoumání mimořádně hodí. To snad částečně osvětluje, proč v nadpise hovořím o Kvaszově verzi absolutním idealismu, s detaily, které bude třeba podrobně probrat. Začal bych návratem $\mathrm{k}$ uvedenému citátu.

\section{Zabudování jazyka do jazyka}

Úsudek ze struktury nějakého objektu, např. důkazu nebo výrazů aritmetiky, na jeho obsah je typický pro metamatematická zkoumání, jak je do matematiky spolu s celým aparátem Fregovy matematické logiky prosadil Hilbert. Použití těchto metod se ale stalo tak četné a významné, že se již zapomíná, jak je netriviální, a raritní př́ípady, v nichž je přece jen stále patrné, např. v Gentzenově důkazu bezespornosti aritmetiky či v důkazu Goodsteinovy věty, se zdají spíše potvrzovat pravidlo.

2 Týž, Patterns of Change. Linguistic Innovations in the Development of Classical Mathematics, Basel 2008, str. 162.

3 D. Dath, Hegel, Stuttgart 2020, str. 47. 
Toto sebezapomínání každé vědy nyní Kvasz cíleně rozhýbává a oživuje dalšími příměry, především působivou analogií s geometrii a přechodem od perspektivní malby $\mathrm{k}$ malbě, $\mathrm{v}$ níž je tato perspektiva sama tématem. Ukazuje se totiž, že pohled mimo obraz, jímž se řídí perspektivní malba, je třeba - pro korektní zachycení, jak se ustanovovalo po několik staletí - určitým způsobem učinit předmětem srovnání, tedy předmětem malby samé. Kvaszovým modelovým př́kladem jsou Dürerovy rytiny, v nichž jsou techniky perspektivního zobrazování samy zobrazovány. Tato malba přitom podle Kvasze obsahuje dvojí vhled do podstaty zobrazování. První vhled bych schematizoval takto:

(G1) Srovnání obrazu se skutečností je vlastně vždy pouze srovnání obrazu s obrazem, totiž skutečnosti, jak se nám jeví, se skutečností, jaká je o sobě, což ale znamená, jak se nám jeví z jiného úhlu pohledu, který prohlásíme za realistický.

Kvasz přitom (jinde) upozorňuje, že koncept „realistické“ malby nemá žádné přirozené naplnění, tj. není například důvod, proč malovat věci v perspektivním zkrácení, když jsou „ve skutečnosti“ stejně velké, nebo proč jako v egyptské malbě nepreferovat zkracování úměrně společenskému postavení spíše než vzdálenosti od externího pozorovatele. Zde je druhý vhled:

(G2) Explicitní znázornění formy obrazu, toho, jak zobrazuje, nás vede k použití nové implicitní formy, totiž k zaujetí postoje toho, kdo danou formu činí prvkem nového obrazu.

V těchto dvou základních geometrických postřezích se odráží něco, co bych chtěl nazvat Kvaszovým základním filosofickým postřehem, jejž on sám zakládá na teorii Wittgensteinova Tractatu. Formulujme ho takto:

(F1) Každý obraz jakožto obraz (tedy ne pouhý artefakt, kus plátna na stěně) je dán svojí zobrazující formou, kterou ale v něm samém nelze zobrazit, pouze se v něm ukazuje.

Pro Kvasze je příkladem prvku formy, která se v obrazu ukazuje, ale není v něm zobrazena, horizont perspektivní malby. Pokud bychom podle autora $\mathrm{k}$ horizontu malby šli, nenašli bychom jej. Je tedy formální vlastností obrazu, kterou si malîrí mohli, spolu s dalšími perspektivními pomůckami - třeba s distančním bodem, jenž nám umožňuje určit nejen 
výšku očí, ale i vzdálenost pozorovatele - načrtnout na obraz, obdobně jako wittgensteinovské logické lešení světa, před jeho vlastní konstrukcí, nikoli při ní.

Rozdíl Kvaszova čtení postřehu (F1) oproti čtení Wittgensteinovu spočívá v tom, že Kvasz vidí kontrast formy a obsahu jako dynamický, imanentně přispívající $\mathrm{k}$ proměnám forem zobrazení, jak je to možné sledovat ve vývoji malîrství či geometrie, což ve své nejnovější knize popisuje, ale i v dějinách lidstva jako takových, k čemuž dospívá v jejím závěru. Tato pointa je podstatná pro výše zmíněné systematické čtení Kvaszova filosofického počinu a fakticky jej přibližuje Hegelově filosofii, nebot' Tractatus má zjevné kantovské rysy transcendentálního pojetí filosofie, včetně těch, které volají po svém „hegelovském“ překonání. Onen hegelovský zvrat, překonání transcendentalismu, přitom Kvasz formuluje explicitně v úvodu své nové knihy, jako tezi o zabudování zobrazení jazyka do jazyka:

(F2) Forma zobrazení jazyka, kterou nelze v tomto jazyce vyjádřit, ale lze ji jen ukázat, se může do jazyka zabudovat. Tím vznikne nový jazyk s novou formou zobrazení.

Přesněji řečeno, takovéto teze artikuluje Kvasz tři, z nichž jedna zhruba odpovídá tomu, co jsme formulovali jako (F1), totiž teze o existenci formy zobrazení. Další teze se týká plurality forem zobrazení a systematicky pracuje s možností formu imanentně změnit, a dospět tedy k sérii takto provázaných forem. Tato provázanost je přitom vyjádřena právě tezí (F2) a je řízena v ní popsanou možností vnořit formu jazyka opět do jazyka. Postřeh (F2) tak přirozeně obsahuje i odmítnutí absolutní formy z Wittgensteinova Tractatu, jak bylo formulováno v rámci Filosofických zkoumání, v pojmu řečových her. Podstatné v Kvaszově „hegelovské“ koncepci je nyní především to, že pluralita není pouze konstatována, ale vzniká imanentně, reflexí na možnost učinit formu jazyka jeho předmětem.

\section{Autopoietická struktura matematických forem}

Podstatná je v dalším Kvaszově výkladu právě konkrétnost předkládaného materiálu, tedy př́iklady z matematiky a jejích dějin. Za tím už je určité netriviální předsevzetí, totiž nevidět matematiku a žádnou vědu jako abstraktní disciplínu, ale jako její vlastní dějiny, které se v nějakém 
ohledu stále opakují, totiž když se je jako jedinci pokoušíme pochopit. Kvasz to popisuje nepřímo na vývoji matematického jazyka, který se může měnit, aniž by tím byla „realita“ za ním jakkoli zasažena. Hegelovská lekce je zde rovněž jasná: se změnou poznání (jazyka) se nutně mění i jeho předmět (svět). ${ }^{4}$

V Patterns of Change je tento vývojový rámec popsán svéráznou dialektikou „rekódování“, což ale není nic jiného než uvedená souhra nevyslovitelné formy, hranic určitého zobrazení a jeho expresivních možností, jak jsou v obecnosti tématem Wittgensteinova Tractatu. Ty vyjadřuje (F1), nyní v aplikaci na matematiku. Základní matérie je opět historická. Dějiny matematiky jako vědy, nejen praktického počítání, jak se objevuje ještě v Egyptě, začínají elementární aritmetikou a jejím jazykem daným nějakou sadou číslovek, dnes třeba $1,2,3 \ldots$, a početních operací jako + či $\times$. V tomto jazyce lze formulovat určité matematické problémy, např́íklad pomocí systémů rovnic jako $x+y=10$ či $x \times y=40$. Tím jsou podle Kvasze dány jak možnosti systému, tak jeho limity, nebot' dané rovnice nemusejí mít v některých, např. zrovna v uvedených případech, řešení.

Přechod k další vývojové fázi, jíž je syntetická geometrie, je dán právě reakcí na tyto možnosti, kdy rekódováním aritmetických pojmů na pojmy geometrické, např. rovnic na sčítání úseček $x$ a $y(x+y=z)$ nebo utváření obdélníku o stranách $x$ a $y(x \times y=z)$, nejen rozšiřujeme možnosti toho, co lze vyjádřit, tj. učinit předmětem obrazu, ale také dokážeme vysvětlit, proč to dříve nebylo možné (například když nahlédneme, že zmíněné rovnice po nás požadují konstrukci obdélníka, jenž nemůže, jak lze zjistit snadnou vizualizací, existovat). Podobně se lze zabývat tím, jak syntetická geometrie umožňuje zkonstruovat něco pravítkem a kružítkem, např. odmocninu ze dvou, zjistit její expresivní možnosti a omezení a překonat je $\mathrm{v}$ dalším systému. V syntetické geometrii nap̌r. nedávají smysl rovnice vyššího stupně než tři právě s ohledem na geometrické čtení mocnění, kde $x$ znamená přímku, $x^{2}$ čtverec a $x^{3}$ krychli. $\mathrm{V}$ přechodu k algebře lze naopak čistě symbolicky vyjádřit jakoukoli mocninu a symbolickou analýzou konstrukcí pravítkem a kružítkem nahlédnout, proč jsou určité antické konstrukční problémy, například délský problém zdvojení krychle, odpovídající řešení rovnice $x^{3}-2=0$, neřešitelné: zjednodušeně řešeno, nevedou k řešení rovnic určitého stupně. Stejně tak můžeme v analytické geometrii zjistit, proč nemají určité

4 G. W. F. Hegel, Fenomenologie ducha, přel. J. Patočka, Praha 1960, str. 102. 
algebraické rovnice kořen nebo proč mají kořenů více: příslušné křivky bud'to neprotínají osu $x$, jako třeba $x^{2}+2$, nebo ji protínají vícekrát, jako $x^{2}-2$.

Je zjevné, jakým způsobem lze tuto dialektiku vyjádřitelného a nevyjádřitelného rozvíjet dál, což Kvasz sleduje v krocích přes analytickou geometrii, infinitesimální kalkulus, iterativní geometrii, predikátový kalkulus až k teorii množin. U této konkrétní posloupnosti je zajímavé, že v ní Kvasz identifikuje oscilování mezi tím, co nazývá ikonickým jazykem (syntetická, analytická iterativní geometrie plus, překvapivě, teorie množin), a tím, co nazývá jazykem symbolickým (elementární aritmetika, algebra, infinitesimální a predikátový počet). Toto rozlišení je jistě neostré a spekulativní, v pozitivním i negativním smyslu slova, umožňuje ale právě proto navázat na tradiční rozdíly smyslů a rozumu, názoru a pojmu a obecně i dualitu světa a naší mysli. Smyslem filosofie, jak praví Hegel, je přitom takovéto duality překonat, a to právě v celku, jejž tvoří a konstruují. ${ }^{5}$ Zdá se, že to je nakonec i cílem Kvaszovy schematizace.

\section{Matematika jako své vlastní dějiny}

Proměny jazyka matematiky imanentním zvětšováním jeho expresivní a explanační síly, jež obratem vede ke vzniku nových expresivních a explanačních lakun, schematizuje Kvasz do specifické posloupnosti forem, kterou sleduje odděleně v aritmetice a geometrii. $\mathrm{K}$ tomu patř́ i vedení určitých paralel mezi aritmetickou a geometrickou verzí posloupnosti, jejichž vzájemné podstatné rozdíly však autor také sleduje. Na počátku obou posloupností se přitom nachází již zmíněná perspektivistická forma, převzatá z malîrství a z rozpracované teorie lineární perspektivy. $\mathrm{Z}$ ní pak vede př́má cesta k projektivní formě. Ta je naopak převzata z projektivní geometrie, která studuje určité způsoby promítání, a vztahuje se tím k perspektivistické formě právě jako její expresivní a explanační rozšîr̃ení.

Artikulujeme-li např. pravidla centrální projekce, vidíme, že horizont vzniká na průmětně jako průřez s paprsky, které vysílá oko rovnoběžně se zobrazovanou plochou, a kterým tedy na této ploše, resp.

$5 \quad$ Viz G. W. F. Hegel, Differenz des Fichteschen und Schellingschen Systems der Philosophie, in: týž, Werkausgabe in 20 Bänden, Frankfurt a. M. 1986, II, str. 9-140, zde str. 22 a 25. 
v zobrazovaném světě, nic neodpovídá. Horizont je takto čitelně prvkem obrazu, který přímo nic nezobrazuje, ale jen zachycuje externí stanovisko pozorovatele a druh zvolené projekce. Pokud bychom o zobrazování hovořili - což děláme tehdy, když „vidíme“ na obraze horizont nebo když v jazyce hovoříme o jeho gramatice či o tomto jazyce samotném -, zaváděli bychom tím vlastně do skutečnosti nové, ideální typy objektů. To se děje v matematice průběžně, ale Kvasz právě popsáním celého aparátu explikace a rozvíjení určitých forem zobrazení činí tento jev zcela systematickým, vázaným na určitá pravidla projekce a jejich explikaci, jejíž formulování např́íklad v případě perspektivy trvalo několik staletí. Hilbertovo pozdější zdůvodňování ideálních elementů jako důsledku touhy rozumu po určitých symetriích (napřs. dualitě určitých zákonů) je v tomto ohledu spřízněnou, byt' podstatně chudší racionalizací téhož, u Kvasze navíc doplněnou o rozsáhlou historickou analýzu, a tím pádem i dějinnou podmíněnost, uvažovanou Hegelem, který na ní zakládá svou kritiku Kantova „formalismu“. Zde na ní můžeme založit kritiku Hilbertova formalismu.

Hilbertův důraz na formální rysy matematiky a jeho idea, že lze matematické objekty zavést bud’ strukturálně, jako to, co splní daný systém axiómů, nebo formalisticky, jako znaky, s nimiž operujeme v konkrétním názoru, ukazují ve výsledku právě slabiny ahistorického př́stupu. Tvrdit např́klad, že jsou reálná čísla modelem určitého konvenčně zvoleného systému axiómů, je neadekvátní jednak už strukturálně - nebot' v prvořádových teoriích existují vždy modely různé, neizomorfní struktury -, jednak hermeneuticky. Neplatí jen, že v druhořádových modelech, mají-li plnit svůj účel, je nutné předpokládat, že př́íslušná čísla už existují v oboru dané druhořádové proměnné, resp. tato proměnná musí kvantifikovat přes ,Všechny“ podmnožiny daného universa, k nimž se pak, jsou-li omezené, požaduje supremum. Pokud množinu vážeme např. jen na polynomiální výrazy, dokážeme jako model prodat už algebraická čísla, jak tomu bylo v Descartově době. Ale především není jasné, proč by ta či ona teorie měla vlastně zachytit právě reálná čísla, resp. co ji s nimi $\mathrm{v}$ jejich původním zrodu z měření vlastně váže. Diskuse o nestandardních modelech, které vzniknou často jako nechtěný produkt zmíněných omezení, je jinou ilustrací téhož.

Naopak, existence nestandardních geometrií, totiž modelů Eukleidových axiómů bez postulátu o rovnoběžkách, má právě díky své historii pozoruhodný důvod, jenž před námi názorně vyvstává právě v rámci Kvaszovy „obrazové“ "rekonstrukce. Citujme jiné místo z Kvaszových Patterns of Change: 
„Eukleidovská geometrie studovala trojúhelníky, kruhy atd., ale tyto předměty byly situované takřríkajíc $\mathrm{v}$ prázdnotě. Mnoho z toho, co se stává předmětům při projekci, je určeno pravidly projekce roviny, na které jsou situovány. Viděli jsme to v nejjednodušším případě projekce dvou rovnoběžek. Průsečík jejich obrazů je určen vztahem mezi dvěma rovinami $a$ a $b$. Takže projektivní geometrie zkoumá nejen předměty samotné, ale vnáší do teorie i pozadí (rovinu nebo prostor), na němž jsou tyto předměty situovány. “6

Zde máme nejen pojmově přesné zachycení imanentního zrodu neeukleidovských geometrií z geometrie eukleidovské, ale především způsob, jímž si naše pojmy, zde tedy pojem rovnoběžky či pojem trojúhelníka, podržují jednotu významu, ačkoli dochází k radikální proměně celého pojmového rámce. Řešit, co je geometrie, jednoduše analyticky, seznamem definic či axiómů, nedává zjevně smysl.

\section{Zkušenost geometrie jako zkušenost sebe}

Tímto obsáhlým úvodem jsem se konečně od Kvaszových dřívějších knih dostal ke knize recenzované. Tento úvod byl nutný, nikoli z hlediska prostého čtenáře dané knihy - ten si bohatě vystačí s pestrou mozaikou příkladů a témat, které kniha obsahuje -, ale z hlediska čtenáře, jenž v ní chce zahlédnout onen - mnou, nikoli Kvaszem - postulovaný celek. Nominálně vzato Kvasz jednoduše aplikuje zmíněnou iterativní metodu na vývoj malîrství a geometrie. Opět jsme tedy konfrontováni s perspektivistickou a projektivní formou zobrazení, s jejich obecným vymezením, nyní ale v původní, výtvarné aplikaci:

„Pro perspektivistickou formu je např. typické, že uvažujeme výrazy jazyka jako obrazy skutečnosti viděné ze specifického bodu pohledu, zatímco projektivní forma zavádí reprezentaci reprezentace jako fundamentální inovaci.“7

Úmyslně zde cituji ještě celou pasáž z Patterns of Change, protože se v ní výše artikulovaný vhled (G1) projevuje ve formě zvláště klíčové pro pochopení Kvaszova idealismu a jeho sepětí s geometrickým myšlením.

\footnotetext{
6 L. Kvasz, Patterns of Change, str. $122 \mathrm{n}$.

7 Tamt., str. 162.
} 
Konkrétně jde o Desarguesovu „geniální myšlenku“: nahradit skutečnost jejím obrazem. ${ }^{8}$ Filosofická složka této myšlenky je přitom zcela idealistická, zakotvená v Kantově devíze, že věci jsou nám dány jen v té míre, v níž se nám jeví, nikoli jak jsou o sobě. Kvasz ale současně, právě na pozadí projektivní geometrie, ukazuje jak její slabinu, tak způsob, jak ji korigovat, a to zcela v intencích postupu, který navrhl Hegel, když odmítl Kantův pojem věci o sobě jako chimérický a marný.

Pokud předpokládám, že se mi v obraze jen jeví, jak věci jsou, předpokládám rovněž, že mám možnost nahlédnout skutečnost tak, jak je mimo toto jevení - jednoduše tím, že se podívám za obraz. Kvasz ale správně poznamenává, že např́klad Brunelleschiho objev perspektivních principů spočívá na experimentech, jako je ten popsaný pro prrípad florentinského baptisteria, $v$ němž není srovnáván obraz se „skutečností“", ale s její vědomou úpravou, tedy s obrazem obrazu skutečnosti - baptisterium se jeví v zrcadle připevněném vedle plátna -, tedy při zohlednění určitého typu projekce. Rozdíl mezi jevem a skutečností, Hegelovými slovy, je ve finále vždy jen rozdílem mezi jevem a jevem jakožto jevem, tedy věcí, jak je pro nás a jak je o sobě, což je ale zase jen pro nás, pouze v jiném modu prezentace. Dürerovy obrazy činí tento element zcela explicitním.

Kvasz přitom celý přesun od perspektivistické k projektivní formě popisuje termínem „rozštěpení hlediska“, které je v jeho čtení centrální črtou moderního myšlení a obsahuje jej i Koperníkův výklad hvězdné oblohy: pozorovatel se dívá na pozorovatele a vidí, že svět nerotuje kolem něj, ale kolem Slunce, včetně Země, na níž se tento pozorovatel nachází. ${ }^{9}$ To neznamená zrušení centrální role pozorovatele v konstrukci kosmu, jak je vznik moderní astronomie standardně líčen z „objektivních“ pozic současné, údajně bezperspektivní vědy, ale naopak je tato pozice dále cizelována: $K$ jejímu zaujetí, říká se zde, potřebuje vědomí vystoupit mimo sebe. Tento krok je ale učiněn opět v tomto vědomí samém, což se odráží zvláště výrazně už v Kantově rozlišení empirického a transcendentálního já.

Ve výsledku se ale jedná o rozštěp sociální, spočívající v internalizaci druhých. Tato myšlenka je důsledně rozvíjena právě v Hegelově filosofii, kde je Kantův transcendentální systém společensky naturalizován. Kvasz $\mathrm{k}$ tomu přidává svoje upřesnění v závěru knihy, když komentuje již dříve zavedenou posloupnost forem a člení ji opět do dvou střídajících se fází:

8 Viz L. Kvasz, Prostor mezi geometrií a malírstvím, str. 70.

9 Tamt., str. 59. 
„Formy zobrazení uvedené v levém sloupci schématu ... odpovídají zrodu nového druhu subjektivity, nové zkušenosti sebe. Naproti tomu formy zobrazení stojící v pravém sloupci vnášejí do této zkušenosti sebe pluralitu, přinášejí zkušenost jiného. Perspektiva vyjadřuje to, jak já vidím svět, pomocí projektivní formy dokážu pochopit, jak vidí svět někdo jiný. Koordinativní forma vyjadřuje to, jak já vnáším řád do své zkušenosti, zatímco kompozitivní forma umožňuje srovnání mé zkušenosti se zkušeností druhého. Interpretativní forma vyjadřuje to, jak já rozumím své zkušenosti, integrativní forma mi poskytuje možnost porozumět zkušenosti druhého. Konstitutivní forma vyjadřuje to, jak já konstituuji sebe, konceptuální forma mi odkrývá možnost porozumět sebekonstituci jiného. Popsaná dynamika vývoje epistemického subjektu je tedy dynamikou setkávání se se sebou a setkávání se $s$ jiným.“10

Absolutní povaha tohoto řešení je přitom návodná, protože usmiřuje perspektivně nekonečné střídání mezi já a ty v celku společnosti, v níž je překonán prostý subjektivní názor ve prospěch nikoli nadsubjektivního názoru jakési společenské superentity, ale v žánru jeho korigujícího se upřesňování. Skrze něj se, Hegelovými slovy, já stává my a my já. ${ }^{11}$ Kvasz je v tomto ohledu zcela explicitní, když píše:

„Bez setkání s jiným člověku hrozí uvíznutí na povrchu sebe, uvíznutí ve vrchních vrstvách vlastní subjektivity. Platí to však i obráceně. Každému setkání s jiným musí předcházet setkání se sebou samým. $\mathrm{K}$ tomu, abych se mohl setkat s jiným $\mathrm{v}$ rámci projektivní formy jako s nositelem alternativního pohledu na svět a odkrýt tak pluralitu vizí světa (což je asi jádrem manýristické fascinace jinakostí), musím se nejdříve setkat se sebou $v$ rámci perspektivistické formy a naučit se vidět svět z pevného hlediska, musím zdisciplinovat své oko." ${ }^{12}$

Tím je dualita subjektu a objektu překonána ve prospěch dialektiky dvou subjektů, které jsou vlastně subjektem jediným. Že k tomuto překonání dokázal Kvasz koherentně dospět na zdánlivě odtažitém a asubjektivním materiálu, jakým je geometrie, byt' se vstřícnější podporou v malî̃ství, je nepochybně unikátní a filosoficky mimořádný výkon - právě proto, že se

\footnotetext{
10 Tamt., str. 231.

11 G. W. F. Hegel, Fenomenologie ducha, str. 135.

12 L. Kvasz, Prostor mezi geometrií a malírstvím, str. 232.
} 
nepohybuje na úrovni pouhé proklamace, ale hmatatelného historického materiálu a aktuální zkušenosti čtenáře s ním.

\section{Narativní forma absolutního ducha}

V tuto chvíli je už vhodné varovat čtenáře, který by z mé prezentace mohl usoudit, že je Kvasz předním proponentem moderního hegelianismu přinejmenším v zemích Visegrádské čtyřky. O Hegelovi se totiž překvapivě v Kvaszových textech nedozví ani slovo. Jejich původní inspirace, možná už méně překvapivě, je fakticky kuhnovská. Celé absolutní rámování Kvaszovy práce tak bezpochyby zůstává mou fantazií. Snad jsem však už předložil dostatečné množství dokladů, že nejde o fantazii zcela svévolnou, ba, s ohledem na Kuhnovu tezi o nesouměřitelnosti, naopak o tvrzení, které je momentálnímu stavu Kvaszova bádání fakticky adekvátnější. Jde mi především o to, že síla recenzované knihy nespočívá pouze v detailu, v němž ovšem dokáže jít do podivuhodné hloubky a průraznosti, ale také ve stipulovaném celku. Ten může čtenáři snadno uniknout, což by však byla škoda právě proto, že celek a daný detail jsou v Kvaszově filosofii podstatně propojeny.

Detaily si přitom čtenář dohledá nepochybně sám, at’ je to Kvaszova „vychylující“ analýza manýrismu, jeho spojení Velázquezových Dvorních dam s Beltramiho modelem neeukleidovské roviny, Cézannova taktilizace vizuálního prostoru, topologické čtení Picassa či Kvaszovy poznámky ke konceptuálnímu umění jako objevu výrazové svobody podobné té, kterou Cantor svou teorií množin mínil zařídit pro matematiku, abych jmenoval alespoň některé. Z hlediska toho, co sleduji já, jsou nejpodnětnější závěrečné pasáže knihy, resp. kapitoly nazvané Dodatky, v nichž Kvasz zavádí dva nové typy forem, formu narativní a formu scénickou, a diskutuje jejich postavení ve vnímání malîrství a jeho vztahu k obecné zkušenosti. Už souvislost, v níž narativní formu autor zavádí, je překvapivá: jsou jí geometrické konstrukce přítomné v Eukleidových Základech:

„V algebraickém vzorci je pořadí operací potřebných $\mathrm{k}$ jeho výpočtu jednoznačně určeno: víme přesně, co musíme udělat a $v$ jakém pořadí, abychom určili hodnotu daného výrazu. Naproti tomu na geometrickém obrázku nevidíme pořadí kroků konstrukce, jež vedla $\mathrm{k}$ jeho vytvoření. Proto k eukleidovskému obrázku musíme připojit popis konstrukce, tedy narativní text $\mathrm{v}$ přirozeném jazyce, popisující příběh 
konstrukce. Popis konstrukce udává pořadí jednotlivých kroků, jejichž pomocí byla konstrukce vytvořena. Až tento prríběh umožňuje sjednotit prvky obrázku (jednotlivé body, úsečky a oblouky kružnic) do smysluplného celku geometrické konfigurace, která je předmětem geometrie." ${ }^{13}$

Kvasz sám nazývá toto „narativní " pozorování banální - ale ono takové právě není, zohledníme-li malîrrskou analogii a samu problematiku zobrazování, jak je v Kvaszově čtení exemplifikuje především Wittgensteinův Tractatus. Zvolenou analogií je zde přitom, opět nečekaně a působivě, obrácená perspektiva byzantských ikon, která - tak pokračuje navržené čtení - nepředpokládá vnějšího pozorovatele, ale pozorovatele vnitřního. Ten je Kvaszem ztotožněn s vypravěčem - reflektorem, který je v příběhu samém přítomen jako jeho účastník. To řeší výše popsaný problém překonání duality subjektu a objektu způsobem, jenž v sobě zahrnuje i zmíněnou imanentnost a historičnost poznání. Je to totiž právě příběh, jenž překonává nečasovost prostého zobrazení orientujícího se z povahy věci na to, co zde stojí nezávisle na naší teorii, v abstraktním indikativu prostém všech nuancí a konstrukcí přirozeného jazyka, s jeho časy, kondicionály, rody a způsoby.

Narativita se přitom uplatňuje v souhře toho, co lze označit jako minimální příběh naší zkušenosti, s nímž teprve má cenu smysluplně začít. Ten zní: zdálo se, že se má věc tak a tak, a pak se ukázalo, že je tomu ve skutečnosti jinak. Brandom ve svém recentním, byt' desítky let připravovaném komentáři k Hegelově Fenomenologii ducha konstatuje právě toto:

„Myšlenka ,fenomenologie‘ ducha je myšlenkou, že nácvik správného typu zkoumání toho, jak se nám (což znamená sobě) ukázal $d u c h$, odhalí, čím ve skutečnosti vždycky byl. Taková fenomenologie je retrospektivní vzpomínající narativ, v němž je noumenální skutečnost, o níž jsme zjistili, že je již implicitní v různých svých fenoménech a jejich výskytech, činěna explicitní. Tyto výskyty jsou tím, co jsme z této skutečnosti udělali, způsobem, jímž se nám zjevila." ${ }^{14}$

13 Tamt., str. 189.

14 R. Brandom, A Spirit of Trust. A Reading of Hegel's Phenomenology, Cambridge (M.A.) 2019, str. 639-640. 
Že je Kvaszova kniha součástí takovéto „fenomenologie ducha“, je nyní již nepochybně prokázáno. Pro pořádek a větší přesvědčivost doplním ještě jeden citát:

„Vzpomínka (Hegelovo „Erinnerung') proměňuje minulost v dějiny. Transformuje pouhý popis minulých závazků v progresivní narativ posloupnosti lekcí, skrze něž bylo postupně odhaleno, co věci skutečně jsou o sobě (podle něčích současných závazků), a skrze onu progresivní posloupnost stále adekvátnějších jevů to kulminovalo v nějaký současný št’astný stav poznání (tak tento stav vnímáme) toho, jak věci skutečně jsou. Vzpomínající narativ je narativ expresivního pokroku. Je to příběh toho, o čem jsme nyní zjistili, že to tu už celou dobu implicitně bylo v předchozích závazcích, když skutečnost, jež se nám v nich dosud jen zjevovala (noumena za fenomény), postupně vyvstala coby plně explicitní a ukázala se jako to, čím skutečně je v názorech, které v současné době zastáváme a v nichž celý proces kulminoval. Je to příběh o tom, jak se věci o sobě (,an sich') explicitně stávají tím, čím jsou pro vědomí." ${ }^{15}$

Citát z Brandomovy nové knihy zde má i jinou než komparativní funkci: stěžejní je právě jeho důraz na vzpomínání - doslovně „re-collection“-, tedy retrospektivní shrnutí určitých jevů jako podstatných pro jevy současné. Brandom tak na pozadí Hegelovy filosofie zbavuje analytickou, a tím i svou filosofii tradičního ahistorického rámce, jenž chce racionalitu založit čistě z pojmů samých. Zatímco Brandom tak činí do značné míry na pojmové, abstraktní rovině, Kvasz naopak provádí rozsáhlou terénní práci. Ve shrnujících pasážích, jako jsou ty výše citované, se pak oba žretelně setkávají.

Brandom tak, na rozdíl od Kvasze, předkládá podrobnou exegezi toho, jak se zkušenostní narativ stává narativem sociálním, zvláště v pozdějším komentáři $\mathrm{k}$ Hegelově dialektice odpuštění a důvěry jako základu emancipované společnosti. Kvasz oproti tomu zmíněný „,sociální obrat" zmiňuje až v závěru knihy. Dříve ho jen v poněkud větším detailu rozpracovává právě v koncepci scénické formy zobrazení, která koncepci narativní formy doplňuje tím, že vysvětluje, proč je pro pochopení příběhu potřeba aktivní participace obou, vypravěče i čtenáře.

Platí přitom, že jak narativní, tak scénická forma jsou v knize prezentovány jen na zkoušku a nejspíš budou až předmětem autorových dalších

15 Tamt., str. 681. 
úvah, do kterých se, při zmíněném kontextu a rozsáhlém materiálu, může zatím čtenář pouštět sám. Brandomovo výše uvedené shrnutí je přitom relevantní i pro Kvaszovu vývojovou teorii poznání, právě proto, že vývoj forem nečte jen lineárně (či nesouměřitelně), ale právě iterativně: tím, že každá další forma činí explicitním cosi, co již bylo implicitní před ní, jsou už v tom, co předcházelo, prríslušné formy fakticky obsaženy, a tedy stále př́tomny. Hegelovo Absolutno, a jeho předkládané Kvaszovo zpřítomnění, tak není nedosažitelný úběžník, ale stále přítomný a nepřekročitelný kontext našich snah o porozumění světu, a tím i sobě samým.

\section{Závěr}

$\mathrm{V}$ předešlé části jsem fakticky skončil, ale nedá mi to, abych předchozí větu nezobecnil ještě aktuálnějším směrem. Kvaszova kniha nám něco říká nejen o dějinách malîrství a geometrie, ale také o nás samých v podstatně hmatatelnějším smyslu. Nedávno bylo kdesi konstatováno, že v našich zemích máme jen málo filosofư, kteří by měli systém. Pravda je však spíše to, že nemáme mnoho filosofů, se systémem i bez systému, a proto i tam, kde systém je, ho jen obtížně vidíme. Ten totiž vyžaduje nějakou konkrétní práci. Sám Kvasz ji ale za nás celou neudělá. 